\title{
Thermal stress related with mortality rates on broilers' preslaughter operations: a lairage time effect study
}

\author{
Estresse térmico relacionado com taxas de mortalidade durante as operações pré-abate de frangos de \\ corte: um estudo sobre os efeitos do tempo de espera
}

\author{
Frederico Márcio Corrêa Vieira ${ }^{*}$ Iran José Oliveira da Silva $^{\mathrm{I}}$ José Antonio Delfino Barbosa Filho $^{\mathrm{II}}$ \\ Afrânio Márcio Corrêa Vieira ${ }^{I I I}$ Valéria Cristina Rodrigues-Sarnighausen ${ }^{\mathrm{I}}$ Danilo de Brito Garcia ${ }^{\mathrm{I}}$
}

\section{ABSTRACT}

Concerning the reduction of preslaughter death losses, high temperature and relative humidity in the tropics are the major concerns regarding broiler survival prior slaughtering. However, the relationship between different lairage times under controlled environment and the thermal condition outside the holding area is still unclear. Thus, the aim of this study was to compare different intervals of lairage time with different environmental temperature and relationship with poultry mortality rates. A study was conducted in a commercial poultry abattoir in the State of Sao Paulo, Brazil, in the year of 2006. The historical data set from 13,937 trucks, about broiler mortality during preslaughter operations, was given by the abattoir. Factors that influence the welfare of birds were studied, such as lairage time in abattoir and hourly dry-bulb temperature. The statistical analysis was performed using the Double Generalized Linear Models. The lower incidence of death losses before arrival at the processing plant (approximately 13 dead birds per truck) was observed when the lairage time was between 1 to 3 hours, under high temperatures (above $22^{\circ} \mathrm{C}$ ). This effect was more pronounced under critical $\left(25-28^{\circ} \mathrm{C}\right)$ and lethal intervals (above $\left.29^{\circ} \mathrm{C}\right)(12$ and 13 dead birds per truck, respectively). In relation to lairage time, the reduction in mortality rates was more pronounced in the intervals up to 1 hour of lairage under climatized conditions, with a reduction of 3 dead birds per truck. It was concluded that thermal stress have negative influence for broilers welfare kept under preslaughter conditions and variations on mortality rate are strongly related with different lairage times.

Key words: death on arrival, poultry production, thermal comfort, slaughterhouse, welfare.
RESUMO

\begin{abstract}
No que diz respeito à redução das perdas por mortalidade pré-abate, as temperaturas e umidades relativas elevadas nos trópicos são as maiores preocupações quanto à sobrevivência de frangos de corte antes do abate. Entretanto, a relação entre diferentes tempos de espera em ambiente controlado e a condição térmica fora do galpão de espera ainda não está clara. Dessa forma, objetivou-se por meio deste trabalho comparar diferentes tempos de espera com diferentes temperaturas externas e a influência nas taxas de mortalidade de frangos de corte. $O$ estudo foi conduzido em um abatedouro comercial de frangos de corte, situado no Estado de São Paulo, Brasil, durante o ano de 2006. Dados históricos de mortalidade de aves durante as operações pré-abate foram obtidos no abatedouro, provenientes de 13.937 caminhões transportadores de frangos de corte. Fatores que influenciam o bem estar das aves foram estudados, dentre eles, o tempo de espera no abatedouro e a temperatura horária do ambiente externo. A análise estatística foi realizada por meio dos Modelos Lineares Generalizados Duplos. A baixa incidência de mortes antes da chegada à linha de abate foi observada (aproximadamente 13 aves mortas por caminhão) quando o tempo de espera esteve entre 1 e 3 horas, sob altas temperaturas (acima de $\left.22^{\circ} \mathrm{C}\right)$. Esse efeito foi mais evidente nas faixas crítica $\left(25-28^{\circ} \mathrm{C}\right)$ e letal (acima de $\left.29^{\circ} \mathrm{C}\right)(12$ e 13 aves mortas por caminhão, respectivamente). Com relação ao tempo de espera, a redução da mortalidade foi mais pronunciada em intervalos acima de uma hora de espera, sob condições de espera climatizada. Conclui-se que o estresse térmico possui influência negativa para o bem-estar de frangos mantidos sob condição pré-abate e variações na taxa de mortalidade são fortemente relacionadas aos diferentes tempos de espera.
\end{abstract}

Palavras-chave: mortes na chegada, avicultura, conforto térmico, abatedouro, bem estar.

INúcleo de Pesquisa em Ambiência (NUPEA), Escola Superior de Agricultura "Luiz de Queiroz" (ESALQ), Universidade de São Paulo (USP), Av. Pádua Dias, 11, CP 09, 13418-900, Piracicaba, SP, Brasil. E-mail: fredvzoo@ gmail.com. *Autor para correspondência. IIDepartamento de Engenharia Agrícola, Universidade Federal do Ceará (UFC), Fortaleza, CE, Brasil.

"IIDepartamento de Estatística, Universidade de Brasília (UnB), Brasília, DF, Brasil. 


\section{INTRODUCTION}

Nowadays, one of the major problems in the broiler industry is the preslaughter stress, responsible for a great part of the losses on arrival at the abattoir (Death on Arrivals - DOA). Additionally, high temperatures and humidity variations combined with low ventilation in tropical climates might provide significant losses in the preslaughter process. Further problems can occur, such as muscle hemorrhages and increased mortality (KRANEN et al., 1998). Moreover, according to estimates, $40 \%$ of preslaughter losses are related to heat stress, whether by cold or heat (RITZ et al., 2005). The same authors related that the control of temperature becomes a problem in lairage environments if ventilation is not adequate or if environment is not protected from sunlight, in order to reduce mortality, especially considering a temperature peak which promotes an additional stress for the birds.

Whereas the thermal needs of birds ranges between 13 and $27^{\circ} \mathrm{C}$, according with several authors (CURTIS, 1983; SILVA, 2000) and relative humidity between 65 and 70\% (MACARI \& FURLAN, 2001), birds are transported in severe stress condition through the year, indicating the need for concern about preslaughter operations. Considering changes in the average temperature, the lairage environment in the slaughterhouse is the key to reducing the stress caused by previous operations.

Otherwise, one of the most crucial factors to the survival of the bird is the lairage time, which allows an appropriate contact with the birds' environment, reducing the prior heat stress. However, as evidenced by HUNTER et al. (1998), the waiting time in the slaughterhouse can vary from 0 to 7 hours. Thus, the controlled environment makes a decisive role in the desirable duration of lairage time. In environments with little or without ventilation, previous research recommended time intervals less than 2 hours (HUNTER et al., 1998) and between 1 and 2 hours (WARRISS et al., 1999). In climatized environments, the time intervals ranging over 2 hours (QUINN et al., 1998) and BRESSAN \& BERAQUET (2002), through a trial conduced in Brazil, recommended that the ideal time is between 2 and 4 hours, targeting the thermal comfort of birds and consequently a reduction loss. However, the poultry industry still lacks of information about the variation of the length of lairage time and the implications on the welfare and survival of birds prior to arriving at slaughter plants.

Thus, the aim of this study was to compare different intervals of lairage time with different environmental temperature and relationship with poultry mortality rates.

\section{MATERIALS AND METHODS}

The trial was conducted in a commercial poultry processing plant, located in the State of Sao Paulo, Brazil. The historical data set from 13,937 trucks, about broiler mortality during preslaughter operations, was given by the abattoir. The preslaughter information was recorded by the preslaughter staff throughout the four seasons in 2006 (summer, January to March; autumn, March to June; winter, June to September; spring, September to December), and stored in the database of the industry. For each broiler flock, the following data were achieved: stocking density per lorry (number of birds per lorry), density per crate (number of birds per crate), preslaughter mortality (\%) and lairage time (hours). Transport time (hours) and distance between farms and slaughterhouse $(\mathrm{km})$ were not measured and controlled for each flock in the industry. These were recorded only as the general information related to the transport routes through the year.

For each flock arrived at the slaughterhouse, were recorded the preslaughter mortality, which consists in the percentage of dead chickens in relation to the total amount transported per truck, identified at the point of live hanging from shackles on the slaughter line.

Dry-bulb temperature (expressed in ${ }^{\circ} \mathrm{C}$ ) and relative humidity (expressed in \%) was collected at 1-h intervals from the weather station in the city, near the

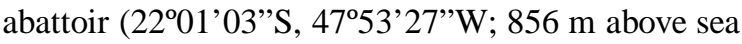
level), from January to December of 2006. The location is under a tropical climate 'Cwa', according to Köppen's classification (KÖPPEN, 1936), characterized by warm and wet season, from October to March, with a mean temperature above $22^{\circ} \mathrm{C}$, and dry season, from June to August, with an average temperature below $18^{\circ} \mathrm{C}$ (EMBRAPA, 2007).

For this work, were evidenced the different external temperature effects, combined with different lairage time intervals. The lairage time was considered the interval between the arrival of the transport vehicles at the holding area and the unloading of the crates with birds into the unloading bay, categorized as short (less than 1 hour), moderate (1-2 hours), medium (2-3 hours) and high (more than 3 hours). This lairage consists of an open building (approximately $23.70 \mathrm{~m} \times 19.22 \mathrm{~m} \times 5 \mathrm{~m}$ high), with galvanized steel roof and 6 metallic trusses. Environmental climatization was achieved by fans mounted on pillars and trusses ( 4 lines of 7 fans each), whilst 8 water misting sets were intercalated with fans, each one with 25 nozzles. The sides had polypropylene panels during summer, to 
protect against direct solar radiation inside the building. This building houses 8 poultry transport trucks, each one with 486 boxes, with the capability for 10 birds per cage. The transported broilers came from commercial farms of the region and varied in genotype (Ross or Cobb), gender and slaughter age (from 6 to 7 weeks). The animals had an average live weight of about $2.5 \mathrm{~kg}$. Before the chickens being caught and crated, feed and water was removed and the length of feed withdrawal period was 8 hours, included within this time all preslaughter operations (catching, crating, transport and lairage at the slaughterhouse). All animals were manually caught by the legs at the farm and were loaded into crates. The crates $(0.75 \times 0.60 \times 0.30 \mathrm{~m})$ were made of plastic material, with perforated walls and floor for ventilation. Each crate had a maximum stocking density of ten chickens $\left(450 \mathrm{~cm}^{2}\right.$ per bird).

Data were analyzed using a Double Generalized Linear Model, an extension of Generalized Linear Models (GLM), which provides a framework for modeling the dispersion in generalized linear models as well as the mean. DOA's were treated as a response variable with Poisson distribution. The logarithmic function $g$ was assumed, to make a link between model linear predictor and expected value of response variable and also for the link function $h(\cdot)$ was also assumed as a logarithmic function which guarantee positive values for the expected dispersion parameter $\varphi$. The Wald statistic was used with the objective to test the hypothesis about the vector $\beta$, that is, to test the true contribution of these factors and interactions on the statistical model (KNIGHT, 2000). This test is an extension of the Student's $t$ test, widely used in general linear regression analysis. Complementary to the Wald test, was performed a residual analysis, to verify the model assumptions, based on deviance residuals, fitted values, q-q plots, scale-location plot and Cook's distance, widely used in GLM analysis (McCULLAGH \& NELDER, 1989). The statistical software R (R DEVELOPMENT CORE TEAM, 2006) was used for estimation.

\section{RESULTS AND DISCUSSION}

The transport time was at acceptable level $(<4 \mathrm{~h})$ and the average distance between farms and slaughterhouse was $120 \mathrm{~km}$, close to the median, indicating that the farms were located relatively close to the slaughterhouse, and time journey was constant during the year.

The density per crate varied around 7 birds, with maximum value of 10 birds per crate. The stocking density per lorry followed the same trend of the density per crate, with average of 3337 birds. The average lairage time varied considerably during 2006, with minimum value of 00:00h and maximum of 17:38h. The same were observed with preslaughter mortality, with minimum and maximum of 0.00 and $10.88 \%$, respectively.

The table 1 shows the thermal variability during the day. Concerning desirable temperature and humidity values for broiler chickens, proposed by several authors (CURTIS, 1983; SILVA, 2000; MACARI \& FURLAN, 2001), during the periods the animals were in heat stress conditions, considering both the temperature and relative humidity effects.

As results of the statistical analysis, a double generalized linear model for mean and dispersion was fitted, followed by a residual analysis. The factors/ covariates and interactions that had a strong significant influence on mortality rates $(\mathrm{P}<0.005)$ were: number of birds per cage vs. periods, external temperature vs. periods of night and morning, seasons vs. periods of night and morning, external temperature vs. lairage time, season autumn vs. lairage time and number of birds per cage vs. lairage time. In this work, were discussed the influence of lairage time in poultry mortality rates, related with different external temperature, as indicated in model (1) for mean effect: $\hat{y}=\exp \left(-5.0110^{-2 \mathrm{NS}}+\right.$ $\left.3.25 \cdot 10^{-2} * \mathrm{t}+4.010^{-3} * \mathrm{e}-9.63 \cdot 10^{-5 *} \mathrm{te}\right)$, where NS nonsignificant; * significantly difference $(\mathrm{P}<0.05)$ derived by Wald test; $\hat{y}$ : expected mean parameter; $t$ : dry-bulb temperature; $e$ : lairage time;

For dispersion effect, the model (2) were used: $\hat{\phi}=\exp \left(2.79 *+34.12 * \mathrm{t}_{\mathrm{o}}+26.15 * \mathrm{t}_{\mathrm{o}}{ }^{2}+9.88 * \mathrm{t}_{o}{ }^{3}+\right.$ $0.15 * n-1.29 * f-0.56 * i-0.61 * p)$, where ${ }^{\text {NS }}$ nonsignificant; $*$ significantly difference $(\mathrm{P}<0.05)$ derived by Wald test; $\hat{\phi}$ : expected dispersion parameter; $t_{o}, t_{o}{ }^{2}$, $t_{o}^{3}$ : third degree polynomial for dry-bulb temperature; $n$ : night; $f$ : autumn; $i$ : winter; $p$ : spring.

The figure 1 shows the influence of thermal variability on mortality rates, when submitted to different lairage time intervals. The effect of the air environment vs. the lairage is very significant in the range of lethal temperature (above $28^{\circ} \mathrm{C}$, with lairage relative humidity around $75 \%$ ), whilst the thermal effect on mortality rates was reduced in comfortable ranges (below $24^{\circ} \mathrm{C}$ ). About lairage time, the major reduce in mortality was observed on lethal range, indicating efficacy of environment control with high lairage time interval.

Birds are submitted to the external environment, especially in the loading and transport, aggravated with the high density per cage, where recorded temperatures are often greater than the external environment (WEBSTER et al., 1993; MITCHELL \& KETTLEWELL, 1998; NIJDAM et al., 2004; YALÇIN et 
Table 1 - Summary statistics of environmental condition throughout the study.

\begin{tabular}{llcccc}
\hline Factors & Period & Minimum & Mean & Maximum & Standard Deviation \\
\hline \multirow{3}{*}{ Temperature $\left({ }^{\circ} \mathrm{C}\right)$} & Morning & 11.0 & 20.3 & 27.0 & 3.0 \\
& Afternoon & 18.0 & 25.2 & 33.0 & 3.0 \\
& Night & 9.0 & 18.1 & 25.0 & 3.0 \\
\multirow{2}{*}{ Relative Humidity $(\%)$} & Morning & 55 & 80 & 96 & 11 \\
& Afternoon & 21 & 63 & 95 & 17 \\
& Night & 85 & 86 & 95 & 10 \\
\hline
\end{tabular}

al., 2004). In this study, during most part of day, temperature values jointly with relative humidity indicated a harsh condition for broiler transportation, especially during morning and afternoon, when maximum temperature and relative humidity were above $25^{\circ} \mathrm{C}$ and $90 \%$, respectively. The condition of heat stress is reduced on the lairage with environment control, where it is expected low temperatures compared with the external temperature. However, the metabolic heat produced by the birds built a thermal gradient between cages and environment (KETTLEWELL \& MORAN, 1992; MITCHELL \& KETTLEWELL, 1994). Given the heterogeneity between the internal and external layer of boxes in the truck, holding birds on an environmentally controlled lairage for a longer period is essential (QUINN et al., 1998; BRESSAN \& BERAQUET, 2002).

BAYLISS \& HINTON (1990) reported that lower mortalities $(0.2 \%)$ were observed in lairage with efficient environment control, with water mist and forced ventilation. In lairage areas where only fans were adopted, without shade to protect the birds against direct solar radiation, the mortality rate achieves values of $0.64 \%$. Confirming these findings, the results of this study indicated a mean preslaughter mortality of $0.33 \%$ and an approximated mortality reduction of $0.1 \%$ when

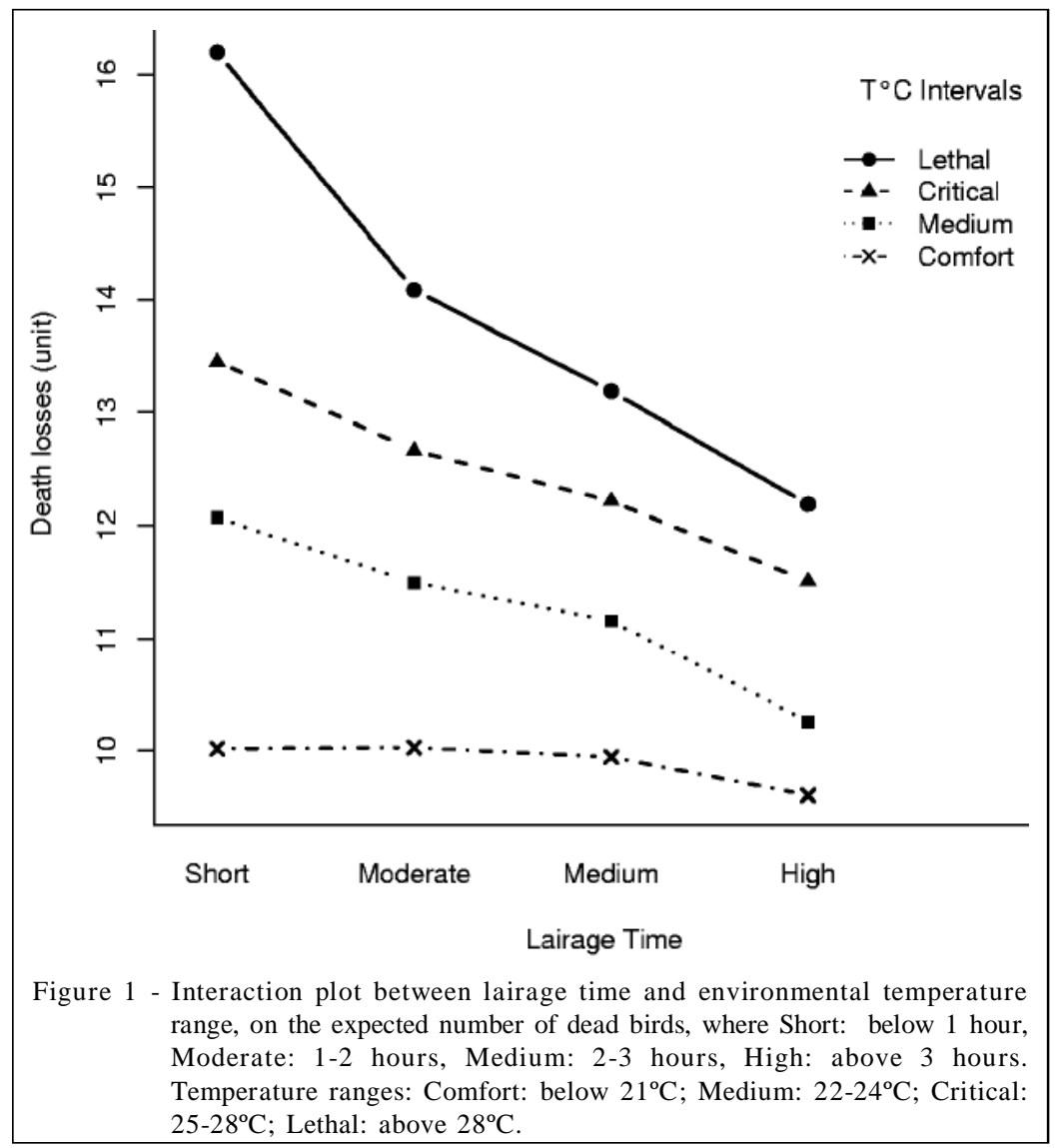

Ciência Rural, v.41, n.9, set, 2011. 
lairage time was increased from below 1 hour to 3 hours. FURLAN et al. (2000) found satisfactory results in the first 10 minutes with the gradual increase wind speed, related to the broilers body temperature, when the environmental temperature was high (above $29^{\circ} \mathrm{C}$ ) and average relative humidity of $66 \%$. However, even in heat stress, the use of forced ventilation promotes a cooling towards the core to the periphery of the body of the bird, promoted by the loss of latent heat (BALNAVE et al., 1998; LOTT et al., 1998). Moreover, RITZ et al. (2005) showed that the environmental temperature has great influence on mortality at the stage of lairage, which increases the concern by the adoption of environmental control, through a waiting time that allows the birds to return to thermal balance, and therefore enhance the survival of the flock. Concerning this point, in this present study the effective reduction of mortality was observed after 1 hour of exposition to climatized environment. Therefore, the chickens are thermally comfortable in a controlled environment, within a space of time allowing the heat exchange and thus reducing body temperature.

Regarding these present results, under thermal comfort range, efficiency of environmental control is reduced gradually (below $21^{\circ} \mathrm{C}$, relative humidity around $75 \%$ ). Due the transport under comfort situations, the mortality rates are not influenced by the thermal condition of lairage module, related to lairage time intervals. However, increasing the lairage time for temperatures above $25^{\circ} \mathrm{C}$, the efficiency on mortality reduction is remarkable, since that the environment conditions are well controlled, facilitating heat exchanges between birds and environment. These results are in agreement with QUINN et al. (1998), who reported that the temperature inside the lorry were significant higher during 1 to 2 hours of lairage, after which the thermal conditions were constant through the time, and this suggested that the minimization of lairage time was not a sufficient control strategy for heat stress. According with these authors, these results shown clearly that higher lairage time intervals were more highlighted effects on mortality under critical temperatures (above $25^{\circ} \mathrm{C}$ ).

\section{CONCLUSION}

Results of this study indicated that thermal stress have negative influence for broilers welfare kept under preslaughter conditions and variations on mortality rate are strongly related with lairage time. Thus, for the different external temperature ranges, the best lairage time was between 1 to 2 hours when below $21^{\circ} \mathrm{C}$, between 2 and 3 hours in the range between 22 to $28^{\circ} \mathrm{C}$ and more than 3 hours for temperatures above $28^{\circ} \mathrm{C}$.

\section{REFERENCES}

BALNAVE, D. Increased utilization of sensible heat loss mechanisms in high temperature, high humidity conditions. World's Poultry Science Journal, v.54, p.69-72, 1998. Available from: <http://journals.cambridge.org/action/ display Is sue ?deca de $=1990 \&$ jid $=$ WPS \& volu meId $=54$ \&issueId=01\&iid=621416>. Accessed: May 5, 2007. doi: 10.1079/WPS 19980006 .

BAYLISS, P.A.; HINTON, M.H. Transportation of broilers with special reference to mortality rates. Applied Animal Behavior Science, v.28, n.1, p.93-118, 1990.

BRESSAN, M.C.; BERAQUET, N.J. Effect of pre-slaughter factors on chicken breast meat abstract. Ciência e Agrotecnologia, v.26, n.5, p.1049-1059, 2002.

CURTIS, S.E. Environmental management in animal agriculture. Ames: Iowa State University, 1983. 409 p.

EMBRAPA. Climate and hidrology. São Carlos: Brazilian Agricultural Research Corporation (EMBRAPA), 2007. Available from: <http://www.cppse.embrapa.br/ servicos/dadosmeteorologicos>. Accessed: Mar. 5, 2007.

FURLAN, R.L. et al. Air velocity and exposure time to ventilation affect body surface and rectal temperature of broiler chickens. Journal of Applied Poultry Research, v.9, p.15, 2000. Available from: <http://japr.fass.org/cgi/reprint/9/1/ 1>. Accessed: Jun. 22, 2007

HUNTER, R.R. Physiological responses of broilers to pre-slaughter lairage: effects of the thermal micro-environment? British Poultry Science, v.39, n.5, p.53-54, 1998. Available from: <http:// w w w. i n f o r m a w o r l d c c m / s m p p / content $\sim \mathrm{db}=$ all $\sim \mathrm{content}=\mathrm{a} 713654425 \sim \mathrm{frm}=$ abslink $>$. Accessed: Jun. 22, 2007. doi: 10.1080/00071669888377.

KETTLEWELL, P.J.; MORAN, P. A study of heat production and heat loss in crated broiler chickens: a mathematical model for a single bird. British Poultry Science, v.33, p.239-252, 1992. Available from: <http://www.informaworld.com/smpp/ content $\sim \mathrm{db}=\mathrm{a} 11 \sim \mathrm{content}=\mathrm{a} 784195183 \sim \mathrm{frm}=\mathrm{abslink}>$. Accessed: Jun. 22, 2007 . doi: 10.1080/00071669208417463.

KNIGHT, K. Mathematical statistics. Boca Raton: Chapman \& Hall, 2000. 504p.

KRANEN, R.W. et al. The effect of thermal preslaughter stress on the susceptibility of broiler chickens differing with respect to growth rate, age at slaughter, blood parameters, and ascites mortality, to hemorrhages in muscles. Poultry Science, v.77, p.737-744, 1998. Available from: <http://ps.fass.org/cgi/ reprint/77/5/737>. Accessed: Sep. 22, 2007.

KÖPPEN, W. Das geographische system der klimate. In: KÖPPEN, W.; GEIGER, R. (Ed.) Handbuch der klimatologie. Berlin: Gebrüder Borntraeger, 1936. p.1-44.

LOTT, B.D. et al. Air velocity and high temperature effects on broiler performance. Poultry Science, v.77, p.391-393, 1998. Available from: <http://ps.fass.org/cgi/reprint/77/3/391>. Accessed: Jun. 25, 2007. 
MACARI, M.; FURLAN, R.L. Environment science on poultry production under tropical climate. In: SILVA, I.J.O. (Ed). Environmental science on poultry production under tropical climate. Piracicaba: FUNEP, 2001. p.146-164.

McCUllaGH, P.; NELDER, J.A. Generalized linear models. London: Chapman and Hall, 1989. 532p.

MITCHELL, M.A.; KETTLEWELL, P.J. Road transportation in broiler chickens: induction of physiological stress. World's Poultry Science Journal, v.50, n.1, p.57-59, 1994. Available from: <http:/ /journals.cambridge.org/action/displayIssue?decade=1990\&jid=WPS $\&$ volumeId=50\&issueId=01\&iid=619444>. Accessed: Out. 13, 2007. doi:10.1079/WPS19940 005.

MITCHELL, M.A.; KETTLEWELL, P.J. Physiological stress and welfare of broiler chickens in transit: solutions not problems. Poultry Science, v.77, p.1803-1814, 1998. Available from: <http://ps.fass.org/cgi/reprint/77/12/1803>. Accessed: Jun. 22, 2007.

NIJDAM, E. et al. Factors influencing bruises and mortality of broilers during catching, transport and lairage. Poultry Science, v.83, p.1610-1615, 2004. Available from: <http:// ps.fass.org/cgi/reprint/83/9/1610>. Accessed: Aug. 29, 2007.

QUINN, A.D. et al. Air movement and the thermal microclimates observed in poultry lairages. British Poultry Science, v.39, n.4, p.469-476, 1998. Available from: <http:/ / w w w. i n f o r m a w o r l d . c o m / s m p p / content $\sim \mathrm{db}=\mathrm{a} 11 \sim$ content $=\mathrm{a} 713654555 \sim \mathrm{fr} \mathrm{m}=\mathrm{abslin} \mathrm{k}>$. Accessed: Aug. 29, 2007. doi: 10.1080/00071669888610.

R DEVELOPMENT CORE TEAM. R: A language and environment for statistical computing, 2006. Available from: <http:// www.R-project.org>. Accessed: May 5, 2007.
RITZ, C.W. et al. Evaluation of hot weather thermal environment and incidence of mortality associated with broiler live haul. Journal of Applied Poultry Research, v.14, p.594602, 2005. Available from: <http://japr.fass.org/cgi/reprint/ 14/3/594>. Accessed: May 5, 2007.

SILVA, R.G. Introduction to Animal Bioclimatology. São Paulo: Nobel, 2000. 288p.

WALD, A. Test of statistical hypotheses concerning several parameters when the number of observations is large. Transactions of American Mathematics Society, v.54, p.426-482, 1943.

WARRISS, P.D. et al. Effects of lairage time on body temperature and glycogen reserves of broiler chickens held in transport modules. Veterinary Record, v.145, p.218-212, 1999. Available from: <http://veterinaryrecord.bmj.com/ content/145/8.toc >. Accessed: Jun. 2, 2007. doi:10.1136/ vr. 145.8.218.

WEBSTER, A.J.F. et al. Thermal stress on chickens in transit. British Poultry Science, v.34, p.267-277, 1993. Available from: < h t t p : / / w w w. in form a w or ld. com/s m p p / content $\sim \mathrm{db}=$ all $\sim$ content $=\mathrm{a} 784254664 \sim \mathrm{frm}=$ titlelink $>$. Accessed: Jun. 22, 2007. doi:10.1080/00071669308417583.

YALÇIN, S. et al. Age-related effects of catching, crating and transportation at different seasons on core body temperature and physiological blood parameters in broilers. Journal of Applied Poultry Research, v.13, n.4, p.549-560, 2004. Available from: <http://japr.fass.org/cgi/reprint/13/4/549>. Accessed: Jun. 22, 2007. 